\title{
Increasing the Productivity and Efficiency of Water Use by Reserving Water
}

\author{
Ali Hassan Hommadi ${ }^{1}$, Wisam Abdulabbas Abidalla ${ }^{2 *}$, Ahmed Sami Naser ${ }^{3}$ \\ ${ }^{1}$ Ministry of Water Resources, State Commission for Dams and Reservoirs, Babylon 51009, Iraq \\ ${ }^{2}$ Al-Mussaib Technical Institute, Al-Furat Al-Awsat Technical University, Babylon 51009, Iraq \\ ${ }^{3}$ Ammara Technical Institute, Southern Technical University, Ammara 62001, Iraq
}

Corresponding Author Email: inm.wsm@atu.edu.iq

https://doi.org/10.18280/ijdne.160208

Received: 26 November 2020

Accepted: 21 March 2021

\section{Keywords:}

water use, reserving sheet, surface irrigation, water productivity

\begin{abstract}
One use of technology in agriculture involves setting up a reserving sheet for subsurface moisture under the root zone of wheat crops, which is symbolized by SWRT, to conserve the water in the root zone. This reduces the field water losses by raising the efficiency of water use (WUE) and economical water productivity (EWP). For this study, an SWRT membrane sheet was put under the root zone of wheat crops throughout the growing season, from the winter of November 2019 to the end of the season in April 2020, in a free field. The study was conducted on a private farm located in the province of Babylon in Sadat Al-Hindya Town, which is approximately $70 \mathrm{~km}$ from the capital (Baghdad). Surface irrigation was utilized for the irrigation of the wheat crops. Two methods were used: method A1 utilized the SWRT sheet and method A2 was conducted without the SWRT sheet. The irrigation water supply, irrigation period, and soil water content before and after irrigation were computed and recorded every day for the A1 and A2 methods. The values of wheat crop production (yield), water use efficiency, and economical water productivity from the two plots were computed and compared. The results obtained for water use efficiency for the two methods, A1 and A2, were 0.51 and $0.47 \mathrm{~kg} / \mathrm{m}^{3}$, respectively. The increment in yield of plot A1 compared with plot A2 was $6.45 \%$. The increment in WUE of plot A1 compared with plot A2 was $8.55 \%$. In addition, the WP of the wheat crop for plots A1 and A2 were 144.44 and $119.16 \mathrm{ID} / \mathrm{m}^{3}$, respectively, while the increment in WP of plot A1 compared with plot A2 was $21.21 \%$. The findings show that the SWRT method prevents the environmental effects of pesticide and fertilizers that enter the groundwater and pollute it. This technology assists in saving water and plant nutrients, and prevents pollution of the groundwater from pesticides and excess fertiliser.
\end{abstract}

\section{INTRODUCTION}

WUE (Water-Use Efficiency) and WP (Water Productivity) terms are of high importance for yield under the influence of stress or full application of water, and form components of water scarcity resistance in plants. Good comprehension, measurement and improvement of WUE and WP constitute a strategic response to overcome water drought and give the best production with minimal water. Mohammed [1] researched the influence of setting up a SWRT sheet under the root zone on water-use efficiency of chili pepper and tomato plants inside greenhouses. The locations of the study were in Diyala and Najaf provinces. The study used SWRT membrane sheet plots, organic matter in plots, tillage in plots, and plots without tillage. The results explained that the water-use efficiency (WUE) of chili pepper in the Diyala governorate with SWRT was higher than other plots, with $233 \%$. In addition, the WUE of chili pepper in the Najaf governorate was higher than other plots, with $165 \%$. Hommadi [2] forecast the use of the SWRT sheet under the root zones of chili pepper crops and okra crops on water-use efficiency (WUE) and economic water productivity (EWP). The study was conducted in two locations in 2019-2020. The surface drip watering system was utilized in the irrigation inside the greenhouse. The results showed increments of WUE and EWP values in the plots with the
SWRT sheet. The WUE value of chili pepper and okra crops was higher than other plots, with a value of $54 \%$ and $25 \%$, respectively. Furthermore, the EWP of chili peppers and okra in the SWRT sheet plot was higher than other plots, with values of $89 \%$ and $108 \%$, respectively.

Salim [3] showed in his research work that the WUE (Water-Use Efficiency) of eggplant crops increased when the SWRT sheet was set up under the eggplant root zone. The case study was carried out inside the greenhouse and outside in the open field during the growing seasons of 2019-2020. Two plots were set up: T1 with the SWRT sheet and T2 without the SWRT sheet. The soil texture used in the experimental research was sandy loam. The results showed that the initial WUE of eggplant was $50 \%$ and in the second season was $41 \%$. Almasraf and Hommadi [4] mentioned that the increment of the EWP of T1, compared with T2 and T3, was $46 \%$ and $170 \%$, respectively. Utilizing the SWRT sheet below the soil surface resulted in an increase in yield, WUE, and EWP, as well as better water conservation and a decrease in water loss via deep percolation. Hommadi et al. [5] stated that the SWRT technique is a new method for reserving water and rain below the surface of the soil of root zones in order to conserve water in the soil profile for a long time. In this research, the WUE and WP for chili peppers inside a greenhouse were computed and compared using 3 methods for chili pepper cultivation: the 
SWRT technique T1, the organic material T2, and the tillage T3. Hommadi and Almasraf [6] utilized the SWRT membrane sheet to prevent water percolation. This study was located in Sadat Alhindya town in Babylon province, Iraq, using the squash crop, which is cultivated in plots watered via trickle irrigation. The study was conducted with two methods: the first utilised the SWRT under the root zone of squash plants Ta with an aspect ratio of 2:1, and the second was conducted without SWRT technology $\mathrm{Tb}$. The results showed that the WUE for the two methods were $6.04 \mathrm{~kg} / \mathrm{m}^{3}$ for Ta and 6.04 $\mathrm{kg} / \mathrm{m}^{3}$ and $4.64 \mathrm{~kg} / \mathrm{m}^{3}$ for $\mathrm{Tb}$. The increment of WUE in method Ta compared with $\mathrm{Tb}$ was $30.17 \%$. Additionally, the WP of squash crops for Ta was $3804.63 \mathrm{ID} / \mathrm{m}^{3}$ and for $\mathrm{Tb}$ was $2373.4 \mathrm{ID} / \mathrm{m}^{3}$. The increment of WP in Ta compared with $\mathrm{Tb}$ was $60.3 \%$. The water conservation of $\mathrm{Ta}$ compared with $\mathrm{Tb}$ was $16.6 \%$. The reduction of the number of irrigations at Ta compared with $\mathrm{Tb}$ was $12 \%$. The objective of this research was to enhance the value of productivity, WUE and EWP with the use of a SWRT sheet under the root zone of wheat. The wheat yield ranges between 0.7 and 4.5 tons/ha in Iraq and Saudi Arabia [7]. Adary et al. [8] discussed wheat yield under supplemental watering in Iraq. They mentioned that yield and WP increased the use of water in conjunction with rain; therefore, wheat yield increased in the first season (from 2.16 to 4.61 ton/ha), which is more than $100 \%$. Abdullah [9] studied the use of SWRT in an open field by planting winter wheat in Anbar province using three methods (T1 including the use of SWRT with sprinkler irrigation and rain feeding; T2, which used SWRT with sprinkler irrigation and rain feeding, with the stress of water; and T3 without using SWRT) in a field area of $40 \mathrm{~m}^{2}$. Abdullah and Almasraf [10] obtained yield and wateruse efficiency for T1 at $0.35 \mathrm{~kg} / \mathrm{m}^{2}$ and $1.66 \mathrm{~kg} / \mathrm{m}^{3}$, and T2 at $0.28 \mathrm{~kg} / \mathrm{m}^{2}$ and $1.28 \mathrm{~kg} / \mathrm{m}^{3}$. The increment of yield in T1 was $25 \%$, while the rise in water-use efficiency in T1 was $30 \%$, more than T2. From this research, $61 \%$ of the water was saved and yield increased by $49 \%$. Crop yield, WUE and EWP of T1 were more than those of $\mathrm{T} 2$ by $49 \%, 16 \%$ and $16 \%$, respectively. AL-Rawi et al. [11] and Miller \& Smucker [12] worked with water-reserving techniques in the subsurface area and using various crops. According to the above survey, further testing of SWRT performance is needed for different crops. This study shows the importance of using a plastic membrane in light and medium-textured sandy soils, and its importance in water-saving and reducing water losses through deep percolation, in addition to increasing productivity, preserving nutrients and fertilizers in the root zone, and increasing the efficiency of water use.

\section{MATERIAL AND METHODS}

\subsection{Study area}

The study area was located in Babylon City $70 \mathrm{Km}$ from Baghdad in the middle of Iraq. Location 1 lies at (430140.52 E: $3614275.50 \mathrm{~N})$ and location 2 lies at (431498.97 E: $3616216.15 \mathrm{~N}$ ), Landsat 8 track (37) path and (168) row (USGS). The location is illustrated in Figure 1. The analysis of the soil research was carried out in the laboratory of the Agriculture Faculty in the University of Baghdad to calculate the soil physical properties, such as soil texture, field capacity (F.C.), permanent wilting point (P.W.P) and specific gravity $(\rho)$. The soil texture of the study area was loamy sand $(0-1.0$ $\mathrm{m}$ depth) and clay (1.0-1.8 $\mathrm{m}$ depth).
In the first layer, the F.C. was $12.9 \%$ by volume and P.W.P was $6.94 \%$ by volume. For the second layer, the F.C. was $35.8 \%$ by volume and P.W.P was $21.2 \%$ by volume. The mass density $(\rho=1.45)$ of loamy sand and the second sand was 1.39 . In addition, the allowable depletion of wheat was $55 \%$ and the high effective root zone of 1.5-1.8 $\mathrm{m}$ [13].

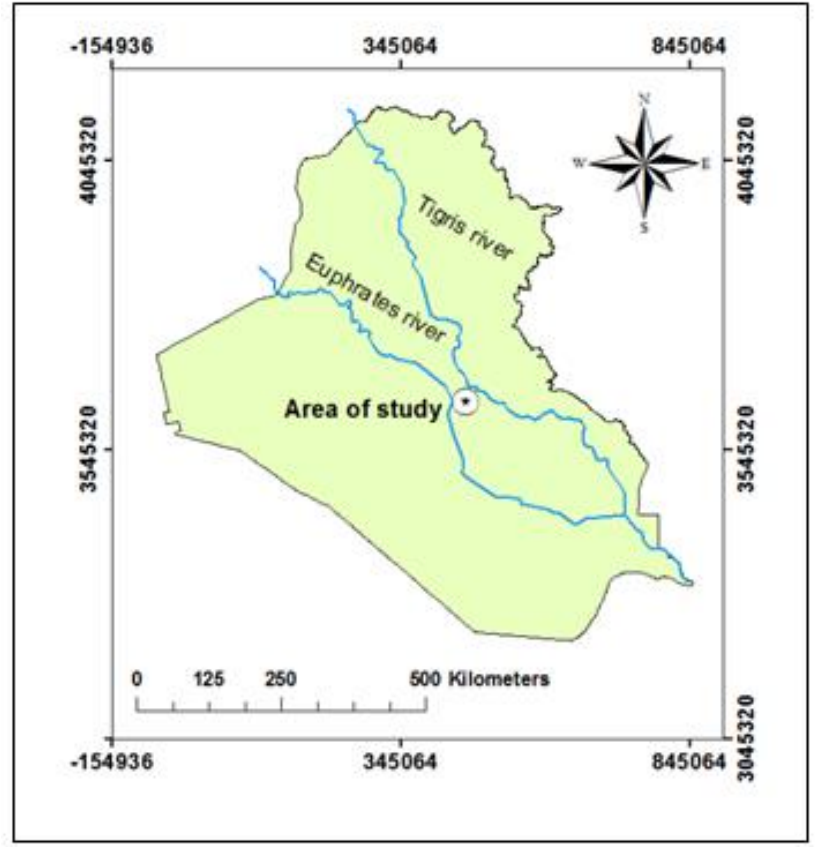

(a)

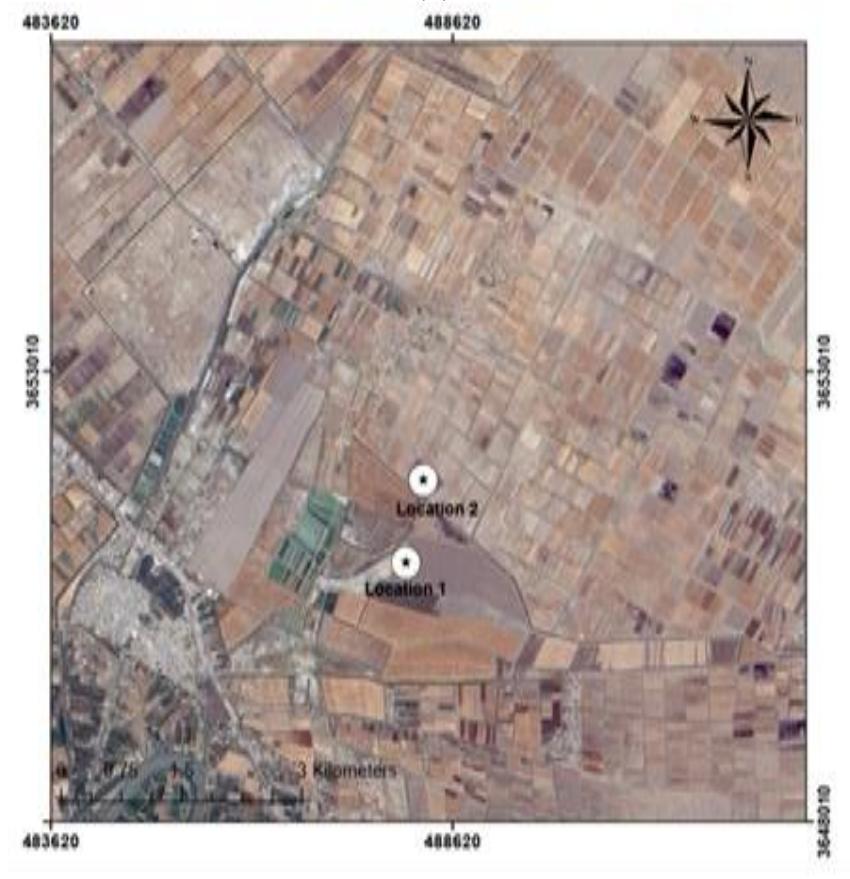

(b)

Figure 1. (a) The location of the study area in the central region of Iraq by GIS; (b) Satellite image of the study area taken from Landsat 8 and processed by GIS

\subsection{Method of the study}

Two methods were used: the A1 method used the SWRT sheet partially installed under the soil surface, and the A2 method was without SWRT. The different methods were used in two areas, and having an area equal to 5.55 square meters 
(length $=7.4 \mathrm{~m}$, width $=0.75 \mathrm{~m})$, with a total area of $22.5(9 * 2.5)$ square metres. The sheet of SWRT with a thickness of $100 \mu \mathrm{m}$ was set up under the soil surface at a depth of 30 centimeters below the root zone of the wheat crops, in a U-shape (like the letter) with the aspect ratio of 2 to 1 (width to height). The installation of the SWRT sheet was conducted via manual work. The cross-section in the site work is explained in Figure 2. Wheat (Tritium aestivum L.) was cultivated in two areas in this project. Surface irrigation was utilized. The date for seeding the wheat crop was at the beginning of the season, in mid-November 2019, and the end of the season, in mid-April 2020. The water pump utilized for the surface irrigation had the highest discharge of 30 liters/minute with a high head of 30 metres and a horsepower of 0.37 kilowatt ( 0.5 horsepower). In addition, supplementary irrigation (surface irrigation with rainfall) was used during the growing season. The amount of $50 \mathrm{~kg} /$ dunum $\left(20 \mathrm{~g} / \mathrm{m}^{2}\right)$ through $5.55 \mathrm{~m}^{2}$ equals 111 grammes for each plot.

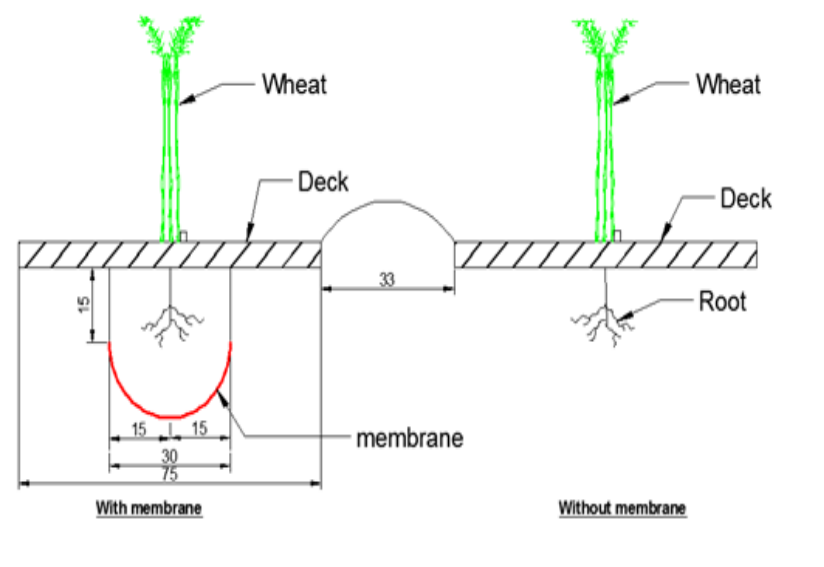

Figure 2. The cross-section of the soil deck

\section{YIELD, WATER-USE EFFICIENCY (WUE) AND WATER PRODUCTIVITY (WP)}

\subsection{Yield}

The full season, from the beginning of seeding until the time of harvesting the wheat, was all counted as production time The wheat yield $\left(\mathrm{kg} / \mathrm{m}^{2}\right)$ was according to [14]:

$$
\text { Total.Yield }=\frac{\text { CropWeight }}{\text { CropArea }}
$$

\subsection{Water-use efficiency}

Water-use efficiency (WUE) was obtained by dividing the wheat yield by the total depth of supplied water. Water-use efficiency $\left(\mathrm{kg} / \mathrm{m}^{3}\right)$ was applied according to [15]:

$$
W U E=\frac{\text { TotalYield }}{\text { total.depth.of.Applyed.Water }}
$$

\subsection{Water productivity}

Water productivity (WP) can be defined as the yield or cost of production divided by the volume of supplied water $\left(\mathrm{m}^{3}\right)$. The value of the yield or cost of production $(\mathrm{kg}$ or in Iraqi Dinar) was equal to the wheat yield multiplied by the market price [16]:

$$
\mathrm{WP}=\frac{\text { production. of. Yield }}{\text { Applyed. of. water. valume }}
$$

\section{RESULTS AND DISCUSSION}

\subsection{Frequency of irrigation and depth of water}

The irrigation schedule was carried out for each method during the growing season. When the AD reached 55\%, this symbolised soil water depletion from the available soil moisture. The months, depth of supplied water, and irrigation frequency (number of irrigation) of wheat in plots A1 and A2 for the growing season 2019-2020 are explained in Table 1. The total depths of supplied water in plots A1 and A2 were 566 and $573 \mathrm{~mm}$, respectively.

The total deficit depths of water in plots A1 and A2 were 450 and $490 \mathrm{~mm}$, respectively. The conservation of water in plot A1 was $12.36 \%$. Method A1 saved the maximum water in the soil root depth compared with A2 because of the SWRT sheet. Rainfall was used as supplementary irrigation with surface irrigation through the growing season (November to May), which is recorded by Alhindya barrage office. Part of this goes to irrigate the crop, and the other part goes on making up for deep percolation losses. The root of the wheat crop was 1.5-1.8 $\mathrm{m}$ according to Allen et al. [13]. The production during the season, from the beginning of seeding until the time of the harvest of wheat was all counted as production time. The wheat yield $\left(\mathrm{kg} / \mathrm{m}^{2}\right)$ was according to Doorknobs [14]

\subsection{Wheat yield and water-use efficiency of wheat crop}

The crop yields, calculated by Eq. (1), for methods A1 and A2 were $0.33 \mathrm{~kg} / \mathrm{m}^{2}$ and $0.31 \mathrm{~kg} / \mathrm{m}^{2}$, respectively. The production for A1 was at a maximum compared with A2, with $6.45 \%$. The increase of wheat crop production in A1 was due to the water and nutrients that were retained in the root zone on the SWRT sheet. Figure 3 explains the yield of the wheat crop at the end of May for A1 and A2. The increment of yield in plot A1 was $6.45 \%$. In addition, the values of WUE for A1 and A2, calculated via Eq. (2), were $0.51 \mathrm{~kg} / \mathrm{m}^{3}$ and $0.47 \mathrm{~kg} / \mathrm{m}^{3}$, respectively. The increment in WUE in A1 compared with A2 was $8.51 \%$. The SWRT helped not only with conserving water and nutrient, but also saving pesticides and preventing the deep percolation process from happening in the roots. Figure 4 explains the WUE values of the wheat crop for A1 and A2.

Standard error (SE), root mean square error (RMSE), and standard bias (BIAS) can be used for the comparison between applied depth (dapp.) and deficit depth (dn); these measures were computed as:

$$
\begin{gathered}
S E=\left[\sum(\text { dapp } .-d n)^{2} / N\right]^{0.5} \\
R M S E=\Sigma[(\text { dapp }-d n) / d a p p] 2 \\
B I A S=\Sigma|(d a p p-d n) / d a p p|
\end{gathered}
$$

where, dapp is the applied depth, dn is deficit depth, and $N$ is a data number. The results of the statistical measurements are shown in Table 2. From these, it was noted that method A1 had the smallest statistical measurement values. 
Table 1. Date, frequency of irrigation, applied depth (dapp.) and deficit depth (dn)

\begin{tabular}{|c|c|c|c|c|c|}
\hline No. & Date & Plots & Freq. Irrigation & Applied depth (mm) & Deficit depth $(\mathrm{mm})$ \\
\hline \multirow{2}{*}{1} & \multirow{2}{*}{$12 / 11 / 2019$} & A1 & \multirow{2}{*}{1} & 41.12 & 37.9 \\
\hline & & $\mathrm{A} 2$ & & 48.5 & 44.25 \\
\hline \multirow{2}{*}{2} & \multirow{2}{*}{$20 / 11 / 2019$} & A1 & \multirow{2}{*}{1} & Rain 33 & 36.9 \\
\hline & & $\mathrm{A} 2$ & & Rain 33 & 38.31 \\
\hline \multirow[b]{2}{*}{3} & \multirow{2}{*}{$26 / 11 / 2019$} & A1 & \multirow{2}{*}{1} & 46.7 & 37.9 \\
\hline & & $\mathrm{A} 2$ & & 46.7 & 41.14 \\
\hline \multirow{2}{*}{4} & \multirow{2}{*}{$8 / 12 / 2019$} & A1 & \multirow[b]{2}{*}{1} & $46.7+12$ rain & 40.8 \\
\hline & & $\mathrm{A} 2$ & & $46.7+12$ rain & 40.5 \\
\hline \multirow{2}{*}{5} & \multirow{2}{*}{$18 / 12 / 2019$} & A1 & \multirow{2}{*}{1} & 42 & 40.9 \\
\hline & & $\mathrm{A} 2$ & & 47.5 & 44.25 \\
\hline \multirow{2}{*}{6} & \multirow{2}{*}{$3 / 1 / 2020$} & $\mathrm{~A} 1$ & \multirow{2}{*}{1} & $46.7+2.5$ rain & 39.1 \\
\hline & & A 2 & & $46.7+2.5$ rain & 39.16 \\
\hline \multirow{2}{*}{7} & \multirow{2}{*}{$20 / 1 / 2020$} & $\mathrm{~A} 1$ & \multirow{2}{*}{1} & 46.7 & 38.77 \\
\hline & & A2 & & 46.7 & 38.82 \\
\hline \multirow{2}{*}{8} & \multirow{2}{*}{$9 / 2 / 2020$} & $\mathrm{~A} 1$ & \multirow{2}{*}{1} & $46.7+13.7$ rain & 40.09 \\
\hline & & A 2 & & $46.7+13.7$ rain & 42.38 \\
\hline \multirow{2}{*}{9} & \multirow{2}{*}{$23 / 2 / 2020$} & A1 & \multirow{2}{*}{1} & 48.5 & 39.42 \\
\hline & & A2 & & 48.5 & 38.12 \\
\hline \multirow{2}{*}{10} & \multirow{2}{*}{$5 / 3 / 2020$} & A1 & \multirow[t]{2}{*}{1} & 48.5 & 40.93 \\
\hline & & $\mathrm{A} 2$ & & 48.5 & 41.82 \\
\hline \multirow{2}{*}{11} & \multirow{2}{*}{$17 / 3 / 2020$} & A1 & & $46.7+12.1$ rain & 38.68 \\
\hline & & A 2 & 1 & $46.7+12.1$ rain & 40.52 \\
\hline & & A1 & & $46.7+10$ rain & 36.12 \\
\hline 12 & $29 / 3 / 2020$ & $\mathrm{~A} 2$ & 1 & $46.7+10$ rain & 36.8 \\
\hline & & $\mathrm{A} 1$ & & $46.7+15.4$ rain & 40.64 \\
\hline 13 & $15 / 4 / 2020$ & $\mathrm{~A} 2$ & 1 & $46.7+15.4$ rain & 43.92 \\
\hline & & $\mathrm{A} 1$ & & $652.42 \mathrm{~mm}$ & $566 \mathrm{~mm}$ \\
\hline & Total & $\mathrm{A} 2$ & 13 & $665.3 \mathrm{~mm}$ & $573 \mathrm{~mm}$ \\
\hline
\end{tabular}

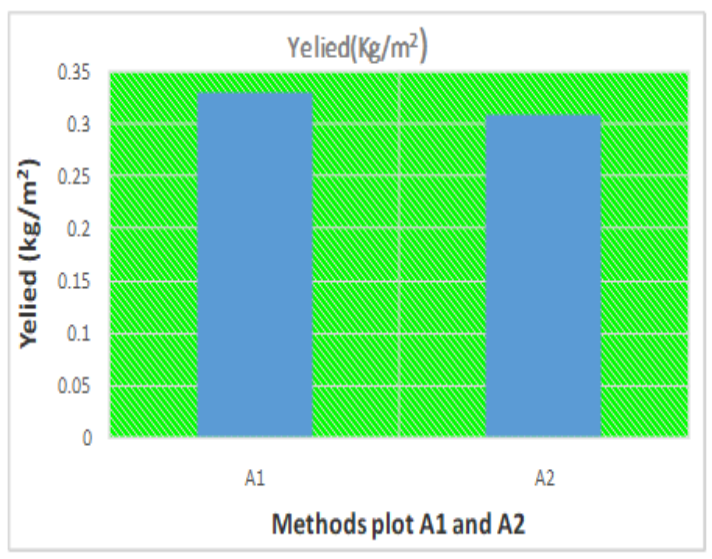

Figure 3. The Yield of wheat between plots $A 1$ and $A 2$ in 2019-2020

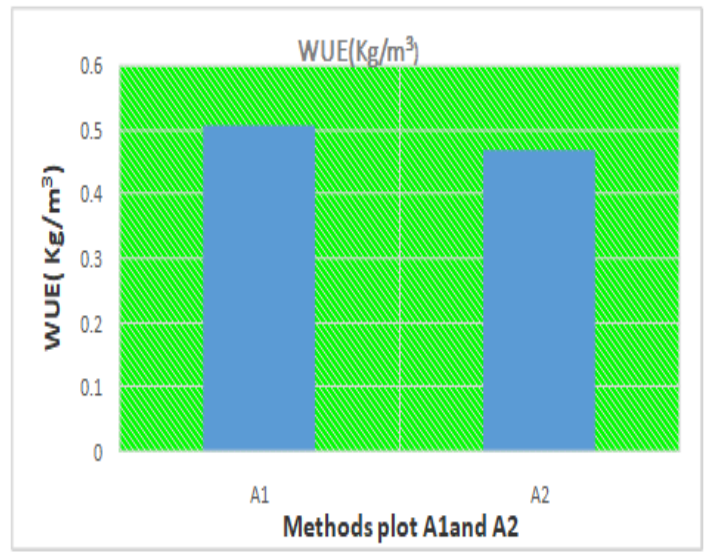

Figure 4. Crop Yield and WUE values for plots A1 and A2 of wheat in the growing season of 2019-2020
Table 2. Comparison between applied depth (dapp.) and deficit depth (dn) using statistical measurements

\begin{tabular}{ccc}
\hline Measures & Method A1 & Method A2 \\
\hline SE & 12.82973 & 13.29701 \\
RMSE & 0.72223 & 2.2260 \\
BIAS & 0.7763 & 2.3613 \\
\hline
\end{tabular}

\subsection{Water productivity}

In this research, water productivity (WP) was calculated by applying Eq. (3). The WP of the plots A1 and A2 were 144.44 and $119.16 \mathrm{ID} / \mathrm{m}^{3}$. Table 3 explains the production, selling price, return, volume of water applied and water productivity of wheat for plots A1 and A2. The value of WP in A1 was at a maximum compared with A2, with $21.21 \%$. The increase in the value of the yield and the reduction in the amount of supplied water was due to the SWRT sheet under the roots, which helps conserve water, nutrients and pesticides in the root zone. Figure 5 shows the water productivity for plots A1 and A2 of zucchini in the growing season of 2019-2020.

Table 3. Production, average total cost, return, net return and applied volume of water and water productivity of all A1 and A2 plots

\begin{tabular}{ccc}
\hline Parameters & Method & Method \\
& A1 & A2 \\
\hline Production (kg) & 1.83 & 1.72 \\
The total cost (ID) & 850 & 850 \\
The total sell price (ID) & 750 & 750 \\
The Return (ID) & 1373 & 1290 \\
The Net return (ID) & 523 & 440 \\
Supplied volume of water (cubic m) & 3.621 & 3.692 \\
Water productivity (ID/cubic m) & 144.44 & 119.16 \\
\hline
\end{tabular}




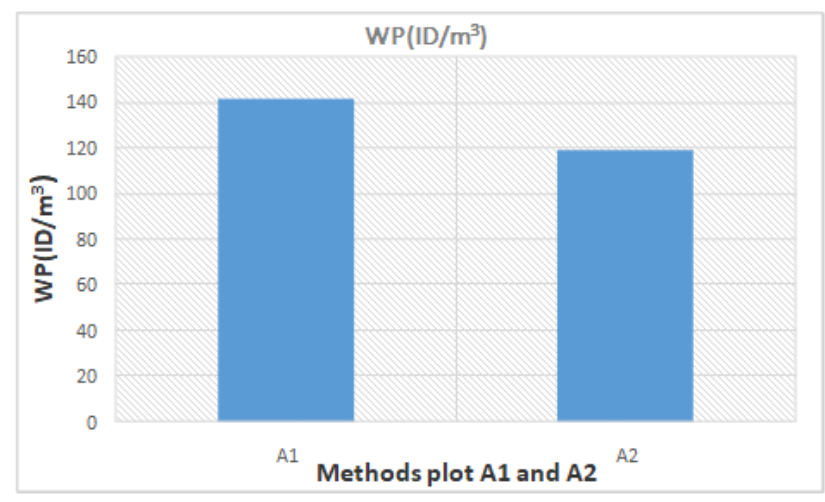

Figure 5. Water productivity for plots $A 1$ and $A 2$ of wheat in the growing season of 2019-2020

\section{CONCLUSION AND RECOMMENDATION}

The utilization of the SWRT under the root zone of wheat crops assisted in saving water and fertilizer, and helps decrease the frequency of irrigation and the quantity of applied water. It obtained the maximum wheat crop yield and water-use efficiency, as well as high water productivity (WP):

The conservation of water in plot $\mathrm{A} 1$ was $2 \%$ compared with plot A2.

The wheat yield in plot A1 was higher than in plot $\mathrm{A} 2$ by $6.45 \%$. In addition to this, WUE in the plot A1 was higher than in plot $\mathrm{A} 2$ by $8.55 \%$.

The value of WP in plot A1 was higher than in plot A2, with $21.21 \%$.

The increment of yield with the maximum selling price of the wheat crop will result in the maximum value of net return with the minimum amount of supplied water.

The SWRT sheet below the soil surface was beneficial in conserving the water supply and nutrients. The membrane sheet will be beneficial in light textured soils and stormy seasons; dry areas could be converted to green areas.

Utilizing SWRT in light textured soils in open field areas of rice and barley crops could improve the yield and WUE.

The utilization of a SWRT sheet could set up multiple layers to change depths, change aspect ratios and change crops.

Using SWRT technique for more than one year would determine the effect of salt on production.

\section{ACKNOWLEDGMENT}

The authors would like to thank the Ministry of Water Resources for their support to achieve this work.

\section{REFERENCES}

[1] Isa, H.A.M. (2016). Effect of SWRT technology on water productivity of tomato and Chili pepper in sandy soil under water scarcity. Doctoral dissertation, $\mathrm{PhD}$ Thesis, College of Agriculture/Baghdad University, Iraq.

[2] Hommadi, A.H. (2018). Evaluation crop evapotranspiration and crop coefficient of squash (zucchini) with subsurface water reserving technology (SWRT) and without SWRT. Journal of Karbala University, 16(3): 47-57.
[3] Salim, A.H. (2018). Improving Field Water Use Efficiency by Using Subsurface Water Retention Technology. MSc thesis in Water Resource department/College of engineering/ Baghdad University, Iraq.

[4] Almasraf, S.A., Hommadi, A.H. (2018). Improving water use efficiency and water productivity for Okra crop by using subsurface water retention technology. Journal of Engineering, 24(7): 64. https://doi.org/10.31026/j.eng.2018.07.05

[5] Abou Hadid, A.F. (2013). Protected cultivation for improving water-use efficiency of vegetable crops in the NENA region1. Good Agricultural Practices for Greenhouse Vegetable Crops, 137.

[6] Hommadi, A.H., Almasraf, S.A. (2019). Water reserving techniques under crops root zone a tool to enhance water use efficiency and economic water productivity for Zucchini. Journal of Engineering, 25(6): 44-52. https://doi.org/10.31026/j.eng.2019.06.04

[7] Curtis, B.C., Rajaram, S., Gómez Macpherson, H. (2002) Bread wheat: Improvement and production. Food and Agriculture Organization of the United Nations (FAO).

[8] Sommer, R., Glazirina, M., Yuldashev, T., Otarov, A., Ibraeva, M., Martynova, L., ... \& De Pauw, E. (2013). Impact of climate change on wheat productivity in Central Asia. Agriculture, Ecosystems \& Environment, 178: 78-99. https://doi.org/10.1016/j.agee.2013.06.011

[9] Phogat, V., Skewes, M.A., McCarthy, M.G., Cox, J.W., Šimůnek, J., Petrie, P.R. (2017). Evaluation of crop coefficients, water productivity, and water balance components for wine grapes irrigated at different deficit levels by a sub-surface drip. Agricultural Water Management, 180: 22-34. https://doi.org/10.1016/j.agwat.2016.10.016

[10] Abdullah, A.H., Almasraf, S.A. (2020). Assessment improving of rainwater reserving on crop yield and crop water use efficiency for winter wheat. Journal of Engineering, 26(3): 46-54. https://doi.org/10.31026/j.eng.2020.03.04

[11] AL-Rawi, S.S., Aoda, M.I., Ati, A.S. (2017). The role of subsurface water retention technology (SWRT) for growing chili pepper in Iraqi sandy soils. Journal of Environment and Earth Science, 7(1): 82-89.

[12] Miller, S.A., Smucker, A.J. (2015). A new soil water retention technology for irrigated highly permeable soils. In 2015 ASABE/IA Irrigation Symposium: Emerging Technologies for Sustainable Irrigation-A Tribute to the Career of Terry Howell, Sr. Conference Proceedings, pp. $1-4$.

[13] Allen, R.G., Pereira, L.S., Raes, D., Smith, M. (1998). Crop evapotranspiration-Guidelines for computing crop water requirements-FAO Irrigation and drainage paper 56. Fao, Rome, 300(9): D05109.

[14] Doorenbos, J. (1977). Crop Water Requirements. Irrigation and drainage paper, 24.

[15] Naroua, I., Sinobas, L.R., Calvo, R.S. (2014). Water use efficiency and water productivity in the Spanish irrigation district "Río Adaja". International Journal of Agricultural Policy and Research, 2(12): 484-491.

[16] Molden, D., Oweis, T., Steduto, P., Bindraban, P., Hanjra, M.A., Kijne, J. (2010). Improving agricultural water productivity: Between optimism and caution. Agricultural Water Management, 97(4): 528-535. https://doi.org/10.1016/j.agwat.2009.03.023 